\title{
Small mammal populations of an agroecosystem in the Atlantic Forest domain, southeastern Brazil
}

\author{
D’Andrea, PS. ${ }^{\text {a* }}$, Gentile, . $^{\mathrm{a}}$, Maroja, LS. ${ }^{\mathrm{b}}$, Fernandes, FA. ${ }^{\mathrm{c}}$, Coura, $R .^{\mathrm{d}}$ and Cerqueira, $R .^{\mathrm{e}}$ \\ áLaboratório de Biologia e Parasitologia de Mamíferos Silvestres Reservatórios, \\ Departamento de Medicina Tropical, Instituto Oswaldo Cruz - FIOCRUZ, \\ Av. Brasil, 4365, CEP 21040-360 Rio de Janeiro, RJ, Brazil \\ bDept. of Ecol. \& Evol. \& Biol., Cornell University, Corson Hall, Ithaca, NY, 14853, USA \\ 'Programa de Pós-Graduação em Biologia Animal, Universidade Federal do Rio Grande do Sul, \\ Av. Bento Gonçalves, 9500, prédio 43323, Porto Alegre, RS, Brazil \\ `Programa de Pós-Graduação em Genética e Biologia Molecular, Universidade Federal do Rio Grande do Sul, \\ Av. Bento Gonçalves, 9500, prédio 43323, Porto Alegre, RS, Brazil \\ 'Laboratório de Vertebrados, Departamento de Ecologia, Universidade Federal do Rio de Janeiro, \\ CP 680202, CEP 21941-590 Rio de Janeiro, RJ, Brazil \\ *e-mail: dandrea@ioc.fiocruz.br
}

Received October 6, 2005 - Accepted November 16, 2005 - Distributed February 28, 2007

(With 4 figures)

\begin{abstract}
This study reports 2 years of the population dynamics and reproduction of a small mammal community using the removal method. The study was conducted in a rural area of the Atlantic Forest, in Sumidouro, Rio de Janeiro State, Brazil. The population sizes, age structure and reproduction were studied for the four most common species in the study area. The overall diversity was 1.67 and ranged between 0.8 to 1.67 . The species richness was 13 considering the whole study. The most abundant species were the rodents Nectomys squamipes $(\mathrm{n}=133)$, Akodon cursor $(\mathrm{n}=74)$, Oligoryzomys nigripes $(\mathrm{n}=25)$ and the marsupials Didelphis aurita $(\mathrm{n}=58)$ and Philander frenatus $(\mathrm{n}=50)$. Seven other rodents were captured once: Necromys lasiurus, Akodon montensis, Sooretamys angouya, Oecomys catherine, Oxymycterus judex, Euryzygomatomys spinosus and Trinomys iheringi. There were higher peaks for diversity and species richness during the winter (dry) months, probably due to higher food availability. The marsupials had a seasonal reproduction with highest population sizes at the end of the rainy seasons. Nectomys squamipes reproduced mostly during rainy periods. Akodon cursor reproduced predominantly in the winter with the highest population peaks occurring during this season. The analysis of the population dynamics of the rodent species indicated that no species behaved as an agricultural pest, probably due to the heterogeneous landscape of high rotativity of vegetable cultivation. Rodent populations were more susceptible to the removal procedure than marsupial ones.
\end{abstract}

Keywords: marsupials, rodents, diversity, long-term study.

\section{Populações de pequenos mamíferos em um agro-ecossistema no domínio da Mata Atlântica, sudeste do Brasil}

\section{Resumo}

Este estudo reporta dois anos da dinâmica populacional e reprodução de uma comunidade de pequenos mamíferos através de método de remoção. O estudo foi realizado numa área rural na Mata Atlântica, em Sumidouro, Rio de Janeiro, Brasil. Os tamanhos populacionais, a estrutura etária e a reprodução foram estudados para as quatro espécies mais comuns na área de estudo. A diversidade total foi de 1,67 e variou entre 0,8 e 1,67. A riqueza de espécies foi de 13, considerando-se o estudo todo. As espécies mais abundantes foram os roedores Nectomys squamipes $(\mathrm{n}=133)$, Akodon cursor $(\mathrm{n}=74)$ e Oligoryzomys nigripes $(\mathrm{n}=25)$ e os marsupiais Didelphis aurita $(\mathrm{n}=58)$ e Philander frenatus $(\mathrm{n}=50)$. Sete outras espécies de roedores foram capturadas somente uma vez: Necromys lasiurus, Akodon montensis, Sooretamys angouya, Oecomys catherine, Oxymycterus judex, Euryzygomatomys spinosus and Trinomys iheringi. Houve maiores picos de diversidade e riqueza de espécies durante os meses de inverno (secos), provavelmente devido ao aumento na disponibilidade de recursos. Os marsupiais apresentaram reprodução estacional com maiores tamanhos populacionais no final das estações chuvosas. Nectomys squamipes reproduziu-se predominantemente durante períodos chuvosos. Akodon cursor reproduziu-se predominantemente no inverno, com os maiores picos populacionais ocorrendo durante esta estação. A análise da dinâmica populacional das espécies de roedores indicou que nenhuma se 
comportou como praga agrícola, provavelmente devido ao ambiente heterogêneo de alta rotatividade de cultivos de legumes. As populações dos roedores foram mais suscetíveis ao procedimento de remoção do que as dos marsupiais.

Palavras-chave: marsupiais, roedores, diversidade, estudo de longo prazo.

\section{Introduction}

Many small mammals show large temporal fluctuations in their numbers. Understanding this phenomenon has ecological, economic and epidemiological implications. Demographic analysis using capture-mark-recapture methods enables one to collect data on population parameters such as reproduction, population density, survival, recruitment and patterns of home range mobility. In removal methods, animals are killed and consequently they are more appropriate to analyse taxonomic issues and collection of samples for DNA extraction and parasitological surveys. Despite the relatively basic demographic data generated by these methods (Seber, 1994), removal methods can nevertheless provide reliable information on population dynamics.

Studies of small-mammal assemblages in Brazil were traditionally conducted in areas of native vegetation (Fonseca, 1989; Cerqueira et al., 1993; Bergallo, 1994; Brito and Fernandez, 2000; Grelle, 2003; Castro and Fernandez, 2004; Pardini et al., 2005). There is almost no available information on the structure and dynamics of small mammal populations in agroecosystems and anthropogenic habitats. Agroecosystems are mosaic landscapes, heterogeneous in space and time, which may cause significant changes in the small mammal assemblage that occupies the area in relation to diversity, demography and habitat use (Utrera et al., 2000). Furthermore, rural environments are of special interest to public health because of the transmission of several zoonoses from wildlife to humans, where small mammal species can act as reservoirs of hantavirus disease (Mills and Child, 1998; Padula et al., 2004; Suzuki et al., 2004), hemorrhagic fevers (Mills et al., 1992b), trypanosomiasis (Herrera et al., 2004; Herrera et al., 2005), leishmaniasis (Oliveira et al., 2005) and schistosomiasis (Rey, 1993; D’Andrea et al., 2000). Moreover, reservoir populations may reach high densities in an "explosive" fashion ("ratada"), making them agricultural pests responsible for heavy economic losses in most of the Neotropics (Rodríguez, 1993). Although these effects have never been quantified in Brazil, there are several personal reports for this phenomenon.

The observation of wild rodents naturally infected with Schistosoma mansoni in the municipality of Sumidouro, Rio de Janeiro State (Silva et al., 1992), has motivated a local eco-epidemiological study. The data analyzed in this paper are part of a long-term research project on the population dynamics of the water rat, Nectomys squamipes, aimed to provide an ecological knowledge basis for the implementation of schistosomiasis control programs, emphasizing the role of the water rat as a wild reservoir. A previous five-year cap- ture-mark-recapture study of small mammals conducted in this area generated data on their general ecology, population dynamics, population genetics, reproduction and schistosomiasis parasitism (D'Andrea et al., 1999; Gentile and Fernandez, 1999; D'Andrea et al., 2000; Gentile et al., 2000; Maroja et al., 2003).

In this paper, we analyze two additional years of a long term study of the population dynamics of Didelphis aurita, Philander frenatus (Didelphimorphia; Didelphidae), Nectomys squamipes and Akodon cursor (Rodentia, Sigmodontinae) using the removal method. We investigate the species richness and abundance, the reproduction and age structure, compared to the previous study of five years carried out in the same locality.

\section{Material and Methods}

\subsection{Study area}

The study was conducted at three localities of the Sumidouro municipality $\left(22^{\circ} 02^{\prime} \mathrm{S}\right.$ and $\left.42^{\circ} 39^{\prime} \mathrm{W}\right)$, State of Rio de Janeiro, Brazil: Pamparrão, Porteira Verde and Bela Joana. Pamparrão and Porteira Verde are adjacent valleys linked by an irrigation channel. The Porteira Verde rivulet was coalescent to Pamparrão's downstream. The landscape included small rural properties with plantations, beef cattle and dairy. Small Atlantic Forest fragments still existed on some mountaintops. Creeks, irrigation channels and flooded areas occur throughout the valleys. The third locality, Bela Joana, was characterized by pasture lands and had chiefly dairy and beef cattle on the right bank of the Paquequer river.

The region has a markedly seasonal humid-mesotermic climate (Nimer, 1989). Water deficit was common during the winter throughout the study period (Figure 1). The mean temperature during the study period was $24.3 \pm 2.4{ }^{\circ} \mathrm{C}$ and the mean rainfall was $121.7 \pm$ $126.1 \mathrm{~mm}$ (meteorological data from the National Institute of Meteorology of Rio de Janeiro for the Carmo station). In this study, six sites were sampled within the three localities (Figure 2). Site 1 had open riparian vegetation with shrubs. Site 2 had an irrigation channel, sparse high trees, shrubs and fodder grass. Site 3 was located along an irrigation channel that linked the Pamparrão and Porteira Verde valleys, with an open vegetation of fodder grass, sparse shrubs and trees, with a riparian secondary forest at the right bank. Site 4 was situated along a small stream in an open flooded grass area. Site 5 had a brook cutting through a marsh covered by continuous dense vegetation of Hedychium choronarium (Zingiberaceae). Site 6, at the Bela Joana locality, bordered a river and has sparse high trees, shrubs and fodder grass. The capture sites 


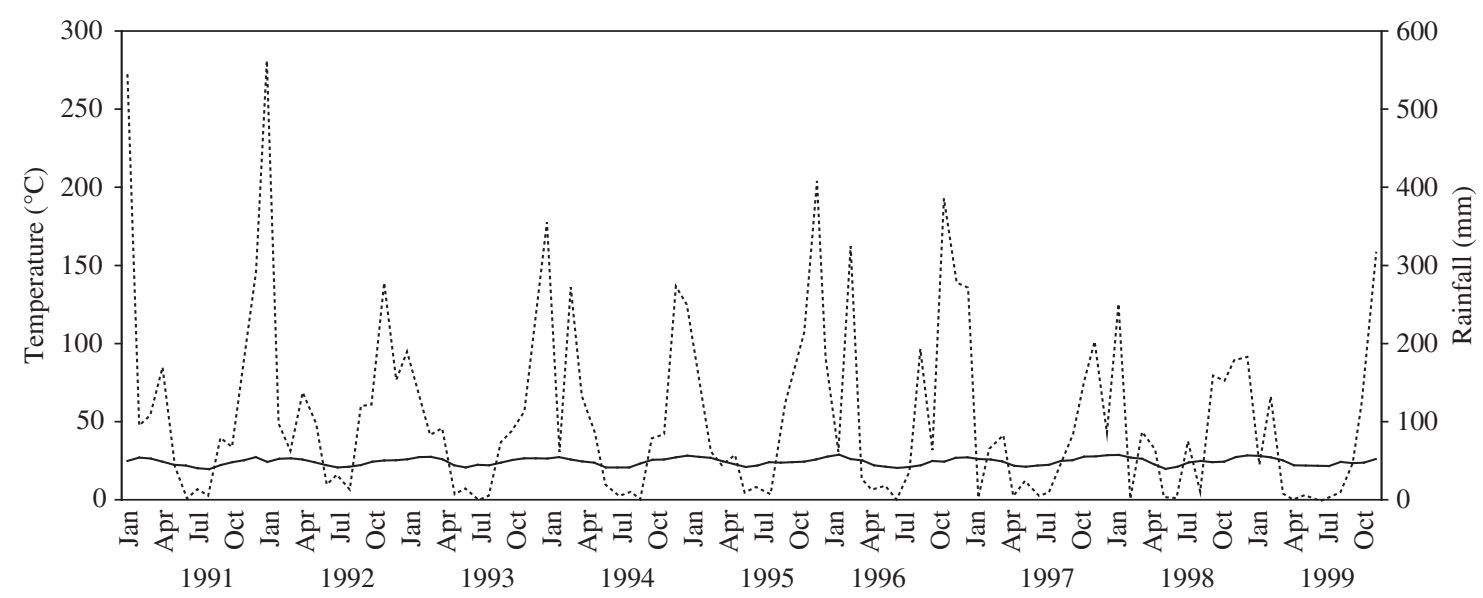

Figure 1. Ombrotermic diagram of the study area in Sumidouro, RJ, Brazil, from January 1991 to December 1999.

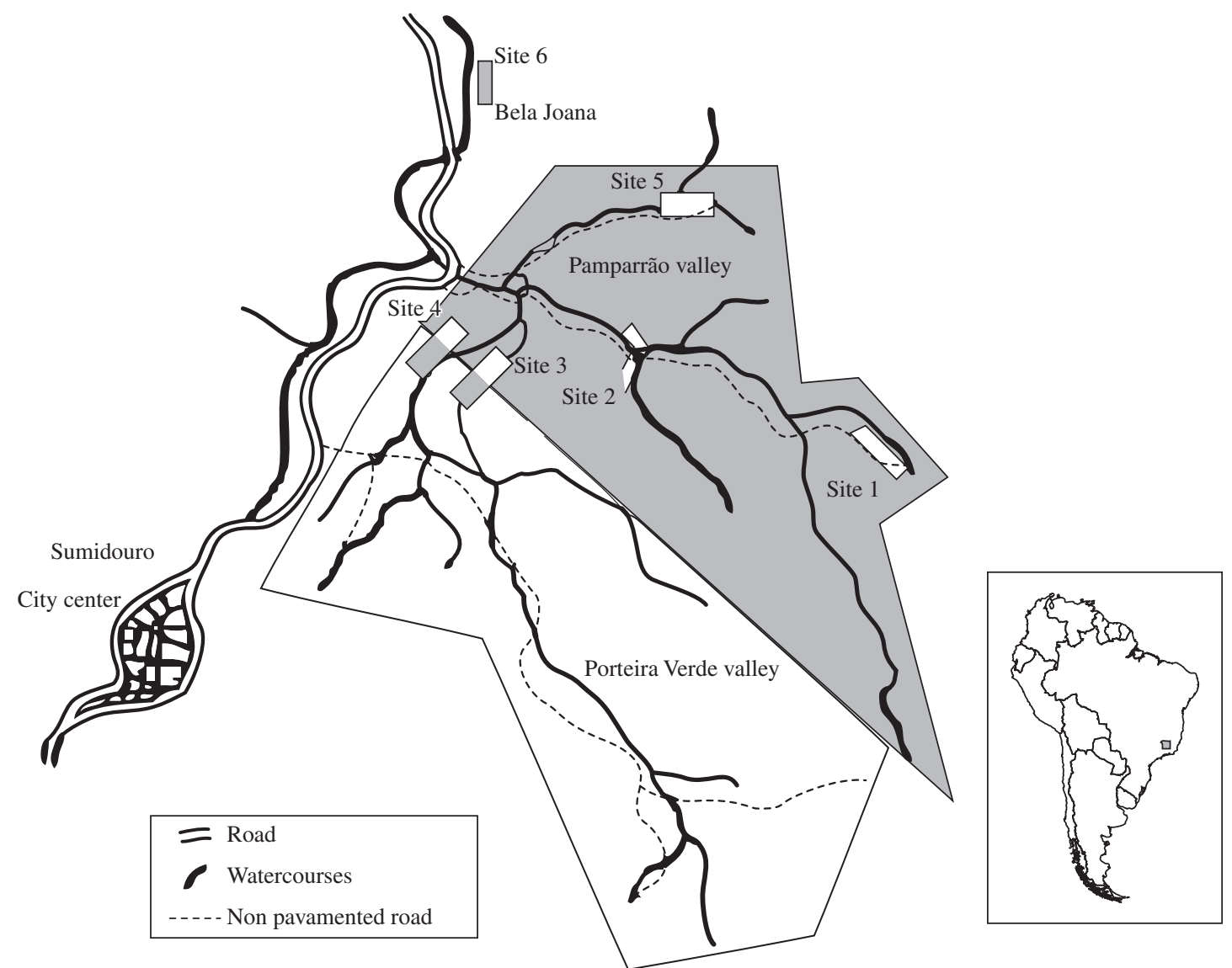

Figure 2. Map o the study area, showing the valleys Pamparrão, Porteira Verde and Bela Joana and the capture sites, in Sumidouro, RJ, Brazil. Author: César Luiz PAC. da Silva.

were established along watercourses and flooded areas. The former design was dictated by the semi-aquatic habits of the water-rat, N. squamipes.

\subsection{Field study}

The removal study was conducted from May 1997 to September 1999. The capture sessions were carried out every other month for five nights at Sites 1, 2, 3 and 4 (15 traps on each site) and four nights at Sites 5 and 6 (10 traps). One wired live trap was placed on the ground at each point spaced 13 meters apart. Traps were baited with a mixture of peanut butter, banana, oats, bacon and manioc. The capture effort was 380 trap-nights per session totaling 5,700 trap-nights for the whole removal study. 


\subsection{Analysis methods}

The population size estimate $(\mathrm{N})$ was considered as the number of animals captured by a regular trapping effort (380 traps for each trapping session). Correlation between population dynamics of marsupials and rainfall was analyzed using the Spearman rank correlation coefficient $\left(r_{s}\right)$, with time-lags from zero to four months. Possible associations of population size among species were also investigated using Spearman's correlation coefficient.

The reproductive period of marsupials was determined by the presence of females with young individuals in the pouch, or with swollen nipples indicating recent weaning. The reproductive condition of rodent females was assessed by the presence of embryos. Males were considered reproductively active when they had scrotal testes. Sex ratios of captured animals were compared using the chi-square test (Zar, 1996).

Marsupial age structures were analyzed by classifying individuals into three classes. The absolute age was estimated by the dental formulas of D'Andrea et al. (1994) for P. frenatus and by the dental formulas of Motta (1988) for D. aurita. Age classes were divided according to Gentile et al. (2000). For P. frenatus, the juvenile class included individuals between 81 and 154 days old, the sub-adult class included individuals from 155 days to 323 days old, and the adult class included all individuals older than 324 . For D. aurita, individuals between 101 and 169 days old were considered juvenile, while they were classified as sub-adults if 170 to 336 days old, and adults if older than 337 days.

Rodent age classes were defined according to body weight and sexual maturity stage. The juvenile class was composed of reproductively immature individuals, weighing less than $110 \mathrm{~g}$ for female and male $N$. squamipes, and 30 and $28 \mathrm{~g}$ for female and male A. cursor respectively. The sub-adult class included individuals in maturity transition weighing between 110 and $215 \mathrm{~g}$ for female $N$. squamipes, 30 and $40 \mathrm{~g}$ for female A. cursor, 110 and $190 \mathrm{~g}$ for male N. squamipes, and 28 and $45 \mathrm{~g}$ for male $A$. cursor. The adult class included sexually mature individuals weighing more than 215 and $190 \mathrm{~g}$ for female and male $N$. squamipes respectively, and more than 40 and $45 \mathrm{~g}$ for female and male $A$. cursor respectively (Gentile et al., 2000).

\section{Results}

\subsection{Species richness and diversity}

We captured eleven rodent and two marsupial species. The most abundant species were $N$. squamipes ( $\mathrm{n}=133)$, A. cursor $(\mathrm{n}=74), D$. aurita $(\mathrm{n}=58$ individuals) and $P$. frenatus $(\mathrm{n}=50)$. Oligroryzomys nigripes $(n=25)$ could also be considered as abundant, but was more sporadically and irruptive. Other rodent species were captured only once: Necromys lasiurus, Akodon montensis, Sooretamys angouya, Oecomys catherine, Oxymycterus judex (Sigmodontinae), Euryzigomatomys spinosus and Trinomys iheringi (Echimyidae). We also captured the antropophilic alien species Rattus rattus $(\mathrm{n}=3)$ close to human habitations. The overall capture success was $5.9 \%$. Species richness reached a value of 13 considering both years, with a mean of $4.8 \pm 1.1$ per capture session (range: 3 to 7). Species richness was higher during the winter months.

\subsection{Population analysis}

Didelphis aurita and Philander frenatus Populations of these species showed seasonal reproduction. Births, young individuals in the pouch and juvenile animals were observed from the end of July to the beginning of April. All lactating females were adult and had complete dental development. D. aurita population was mainly composed of sub-adults. Both species showed a seasonal pattern of a population fluctuation with higher abundance in March or May, just after the end of the breeding season (Figure $3 \mathrm{a}$ and $3 \mathrm{~b}$ ). Abundance of D. aurita with three, four and five months lag was positively correlated with rainfall $(\mathrm{r}=0.357,0.354,0.272$, $\mathrm{n}=45$, respectively, $\mathrm{p}<0.05)$.

Nectomys squamipes - A total of 38 reproductively mature females were captured. Pregnant females were observed throughout the year, except in January, totaling 9 individuals during the study. Litter size was bimodal with 3 or 4 embryos with an average of $3.44 \pm 0.52$. The overall sex-ratio of $N$. squamipes was significantly male-biased (86M:45F, $\left.\chi^{2}=25.55, \mathrm{p}<0.01\right)$. A predominance of adult males and sub-adult females was observed throughout the study. Sex ratio in captivity was 1:1 from birth to weaning (D'Andrea et al., 1996). Nectomys squamipes seemed to reproduce throughout the year, with a reduction of births on dry periods. Predominance of captures of juvenile animals during wet periods confirmed this pattern (Figure 3c).

Akodon cursor - Pregnant females and juvenile animals were captured in dry seasons (Figure 3d), indicating birth periods at the end of wet seasons and during the dry season. Litter size ranged from 2 to 4 with an average of $3 \pm 1$ young. Adults of both sexes were captured throughout the year. Sex ratio in the field did not differ significantly from 1:1 (43M:30F, $\left.\chi^{2}=2.31, \mathrm{p}>0.05\right)$. The abundance of $A$. cursor increased during the winter months showing an annual pattern (Figure $3 \mathrm{~d}$ ).

\section{Discussion}

The observed species richness (13 species) lies in the range of other studies carried out in the Atlantic Forest, where it varied between 8 and 21 species (Fonseca, 1989; Stallings, 1989; Fonseca and Kierulff, 1989; Fonseca and Robinson, 1990; Stallings et al., 1991; Bergallo, 1994; Grelle, 2003; Castro and Fernandez, 2004; Pardini et al., 2005). Despite the study having been conducted in an agroecosystem, the community pattern of richness and abundance of species observed was similar to other studies in preserved areas. The community studied here was dominated by five species, and the others were captured 

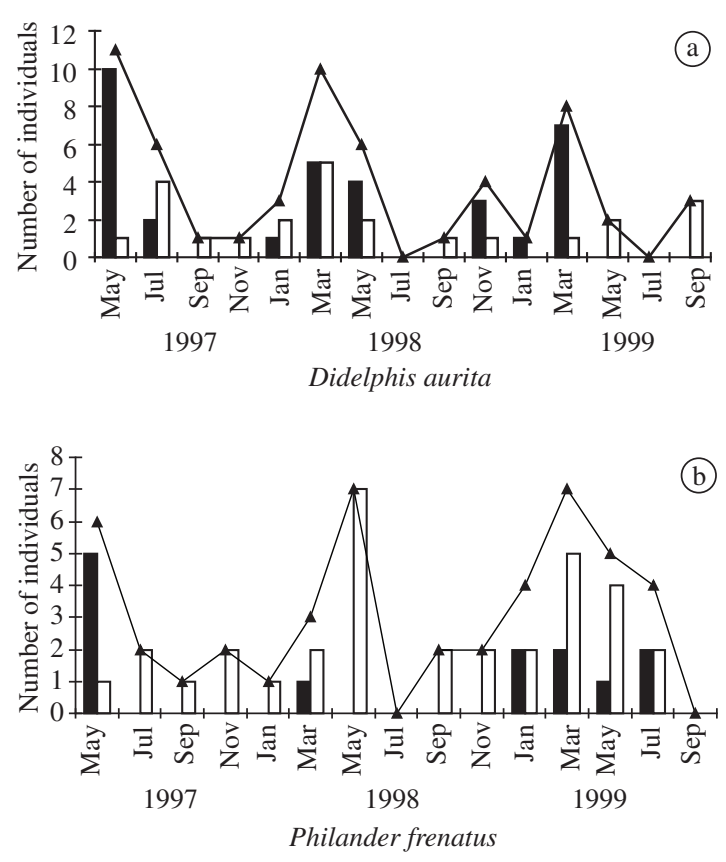

Young+Sub-Adults

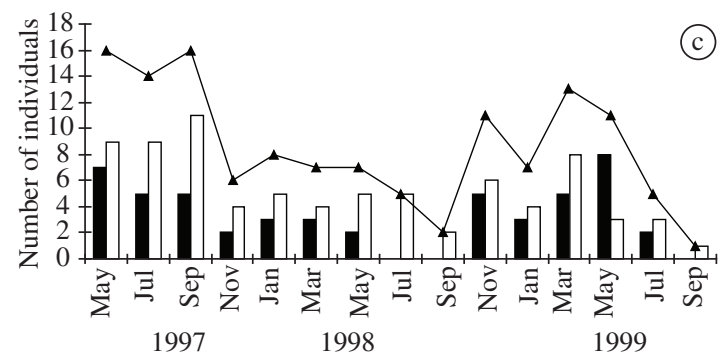

Nectomys squamipes

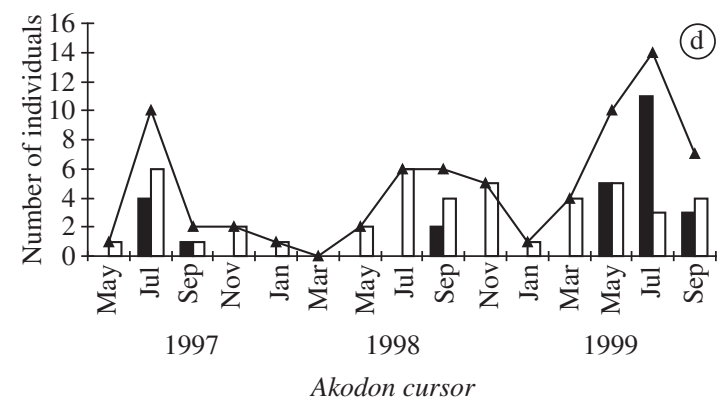

Adults

\section{- Population}

Figure 3. Population size and age structure of a) Didelphis aurita; b) Philander frenatus; c) Nectomys squamipes; and d) Akodon cursor in Sumidouro, RJ, Brazil, from May 1997 to September 1999.

occasionally or only once during the whole study. The study area was a mosaic composed mainly of streamside habitats, open vegetation and disturbed forest fragments, where each habitat had low complexity, and experienced frequent anthropogenic disturbance, such as harvesting, grass cutting and rotative agriculture (Gentile and Fernandez, 1999). A few generalist species with large niche width would be expected to persist even in disturbed areas, such as D. aurita and $N$. squamipes which were the most abundant ones. Although $N$. squamipes is dependent on water bodies, it is generalist in relation to microhabitat and food (Ernest and Mares, 1986; Gentile and Fernandez, 1999).

The observed scarcity of marsupials in this community, represented only by the two most common species of the Atlantic Forest, was the most striking difference from former studies. This situation is probably a consequence of the lack of major contiguous forests (the preferred habitat of marsupials) at the study area. The same pattern was observed by Barros-Battesti et al. (2000) and Briani et al. (2001) in isolated remnants of Atlantic Forest in the State of São Paulo. Other population studies of small mammals carried out in rural areas with monocultures, reported low species richness, but only a few rodent species were present (Mills et al., 1992a; Engel and Mello, 1993). The higher richness during winter months may be related to the higher capture success of the rodent species in the dry seasons (which occur in winter). This pattern may be due to an increase in the abundance of rarer species, or to an enlargement of the home range sizes of some species during these months, which makes them more easily detectable.

Comparing the observed species richness to the data recorded in the previous mark-recapture study carried out in the same study area (D'Andrea et al., 1999; Gentile et al., 2000), three further rodent species (A. montensis, O. judex and Sooretamys angouya) were added to the species list. D'Andrea et al. (1999) reported another marsupial species, Monodelphis americana, and observed a diversity of 1.55 and richness of eleven species, without a clear annual pattern.

The seasonal reproduction observed for marsupials is compatible with the Neotropical pattern observed (Gentile et al., 2004; Cerqueira, 2005). The clear pattern of high population sizes of marsupials at the end of the rainy seasons and beginning of the dry seasons (which coincides with the end of the reproductive season) was due to the recruitment of young and sub-adult individuals born during the previous reproductive season. The same pattern was observed in the previous mark-recapture study (Gentile et al., 2000). Although marsupials had similar population dynamics, there was no correlation of population size among species considering the entire study (eight years), probably because $P$. frenatus had lower numbers of individuals and a little longer reproductive season (Gentile et al., 2000). 
The predominance of reproductive activity of $N$. squamipes during rainy periods had already been reported in other studies (Bergallo, 1994; Bergallo and Magnusson, 1999; Ernest and Mares, 1986). The two more years of population studies reported here clarified the dynamics of this species, suggesting that it could have a multiannual pattern of fluctuation. Rainy seasons could be considered as the most favorable period for reproduction, and for survival of neonates and juveniles, particularly for a semi-aquatic rodent such as $N$. squamipes, when the streamside habitat and food resources are more abundant.

Akodon cursor reproduced opportunistically, predominantly in winter when the highest population peaks occurred. Fonseca and Kierulff (1989) and Pereira et al. (1993) observed the same reproductive pattern, which could be related not only to food but also to habitat availability. The habitat of this rodent in the study area was reduced due to the flooding of marshes and streams, and due to the scarcity of litter and midstore during the rainy periods (Gentile and Fernandez, 1999).

The continuous reproduction of rodents in the Atlantic Forest is attributed to the stability of food resource accessibility (Fonseca and Kierulff, 1989). Although it has been observed that $N$. squamipes and A. cursor reproduced throughout the year, the reproduction of these two rodents may increase significantly in certain periods, stimulated by resource availability according to a rainfall pattern, resulting in population increases. The same pattern is observed in most muroid rodents of temperate regions (Bronson and Perrigo, 1987), and in tropical sigmodontines (Cerqueira and Lara, 1991; Cerqueira, 2005). In captivity, both species reproduced throughout the year (D'Andrea et al., 1996; and unpublished data).

Comparing the population dynamics of the entire study (1991 to 1996 - Gentile et al., 2000; 1997 to 1999 - this study) (Figure 4), we conclude that the removal procedure had a stronger effect in the rodents' population sizes than in the marsupial ones, although annual trends did not change. Marsupials always increased their population sizes along the first semester, while A. cursor always had higher levels between July and October, although its population sizes were smaller during these last two years. Nectomys squamipes population appeared to have a biannual cycle with larger sizes in the odd years and was also susceptible to the removal method.

Opportunistic species, such as herbivore and granivore rodents, might become agricultural pests when occurring at extremely large population sizes. The population dynamics and the abundances of the rodent species studied during these eight years (here and in Gentile et al., 2000) indicated that these species have a low potential to reach extremely high population numbers ("ratadas") and become agricultural pests, probably due to the heterogeneous landscape and to the rotativity of vegetable crop cultivation. The higher susceptibility of these rodents to the removal procedure, when compared to the marsupials, further supports this hypothesis.

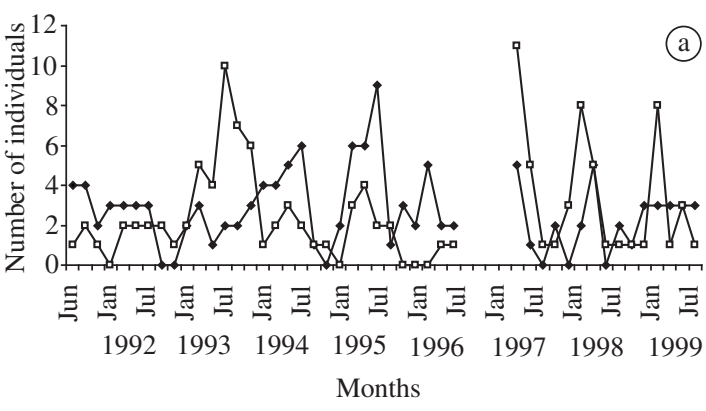

$\rightarrow \rightarrow$ Didelphis aurita $\quad \rightarrow-$ Philander frenatus

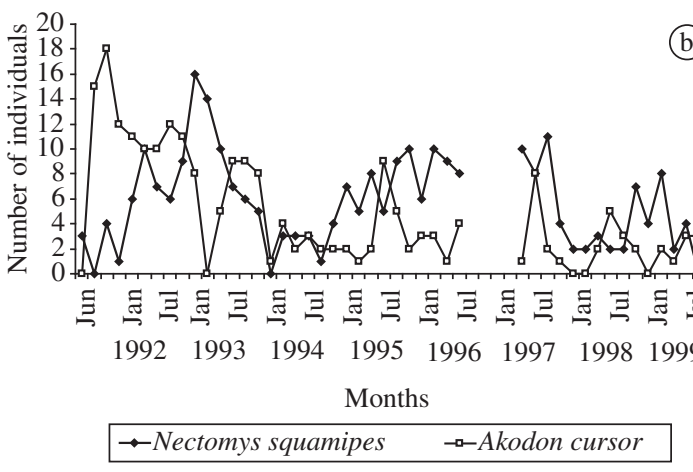

Figure 4. Population sizes of a) Didelphis aurita, Philander frenatus; and b) Nectomys squamipes and Akodon cursor, considering the previous study at Sumidouro, RJ, Brazil, from June 1991 to September 1999.

Acknowledgments - We would like to thank many people who helped us during this study: To L. Rey for the conception of the Sumidouro Project, to JWF. Costa and the people from our lab at FIOCRUZ for help in the field work, to CR. Bonvicino for rodent identification by karyological analysis, to CLPA. Coelho da Silva for providing the study area map, to the people of Pamparrão, Porteira Verde and Bela Joana localities at Sumidouro, who allowed us to carry out the field work in their properties, to the Sumidouro Municipal Government, in State of Rio de Janeiro for many operational facilities. We also thank MV. Vieira and CJ. Bidau for comments and the English review. This work was supported by the Instituto Oswaldo Cruz/ Fiocruz, Papes/Fiocruz, and grants from Conselho Nacional de Desenvolvimento Científico e Tecnológico (CNPq), Fundação de Amparo à Pesquisa do Rio de Janeiro (FAPERJ), FUJB, Ministério do Meio Ambiente/PROBIO. We would also like to thank the Instituto Brasileiro do Meio Ambiente e Recursos Naturais Renováveis (IBAMA) for the collecting license.

\section{References}

BARROS-BATTESTI, DM., MARTINS, R., BERTIM, CR., TOSHINARI, NH., BONOLDI, VLN., LEON, EP., MIRETZKI, M. and SCHUMAKER, TTS., 2000. Land fauna composition of small mammals of a fragment of Atlantic Forest in the State of São Paulo, Brazil. Rev. Bras. Zool., vol. 17, no. 1, p. 241-249.

BERGALLO, HG., 1994. Ecology of a small mammal community in an Atlantic Forest area of South-eastern Brazil. Stud. Neotrop. Fauna \& Environ., vol. 29, no. 4, p. 197-217. 
BERGALLO, HG. and MAGNUSSON, W. E., 1999. Effects of climate and food availability on four rodent species in southeastern Brazil. J. Mammal., vol. 80, no. 2, p. 472-486.

BRIANI, DC., SANTORI, RT., VIEIRA, MV. and GOBBI, N., 2001. Mamíferos não-voadores de um fragmento de mata mesófila semidecídua, do interior do Estado de São Paulo, Brasil. Holos Environm, vol. 1, no. 2, p. 141-149

BRITO, D. and FERNANDEZ, FAS., 2000. Metapopulation viability of the marsupial Micoureus demerarae in small Atlantic forest fragment in south eastern Brazil. Animal Conservation, vol. 3, no. 3, p. 201-209.

BRONSON, FH. and PERRIGO, G., 1987. Seasonal regulation of reproduction in muroid rodents. Am. Zool., vol. 27, no. 3, p. 929-940.

CASTRO, EBV. and FERNANDEZ, FAS., 2004. Determinants of differential extinction vulnerabilities of small mammals in Atlantic Forest fragments in Brazil. Biol. Conserv., vol. 119, no. 1, p. $73-80$.

CERQUEIRA, R. and LARA, M., 1991. Rainfall and reproduction of cricetid rodents in Northeastern Brazil, pp. 545-549. In: B. BOBEK, K. PERZANOWSKI, W. ROGELIN (eds.), Global Trends in Wildlife Management. Swiat Press, Krakow.

CERQUEIRA, R., GENTILE, R., FERNANDEZ, FAS. and D'ANDREA, PS., 1993. A five-year population study of an assemblage of small mammals in Southeastern Brazil. Mammalia, vol. 57 , no. 4 , p. 507-517.

CERQUEIRA, R., 2005. Fatores ambientais e a reprodução de marsupiais e roedores no leste do Brasil. Arquivos do Museu Nacional, Rio de Janeiro, vol. 63, no. 1, p. 29-39.

D'ANDREA, PS., CERQUEIRA, R. and HINGST, ED., 1994. Age estimation of the Gray Four Eyed Opossum, Philander opossum (Didelphimorphia: Didelphidae). Mammalia, vol. 58, no. 2, p. 283-291.

D'ANDREA, PS., HORTA, C., CERQUEIRA, R. and REY, L., 1996. Breeding of the water rat (Nectomys squamipes) in the laboratory. Lab. Animals, vol. 30, p. 369-376.

D'ANDREA, PS., GENTILE, R., CERQUEIRA, R., GRELLE, CEV., HORTA, C. and REY, L., 1999. Ecology of small mammals in a Brazilian rural area. Rev. Bras. Zool, vol. 16, no. 3, p. 611-620.

D'ANDREA, PS., MAROJA, LS., GENTILE, R., CERQUEIRA, R., MALDONADO Jr., A. and REY, L., 2000. The parasitism of Schistosoma mansoni (Digenea - Trematoda) in a naturally infected population of water rats, Nectomys squamipes (Rodentia- Sigmodontinae) in Brazil. Parasitology, vol. 120, no. 6 , p. 573-582.

ENGEL, LA. and MELLO, DA., 1993. Rodents in agroecosystems in the Cerrado Province of the Federal District (Brasilia/ DF, Brazil). Ciênc. Cult., vol. 45, no. 2, p. 128-133.

ERNEST, KA. and MARES, MA., 1986. Ecology of Nectomys squamipes, the neotropical water-rat in Central Brazil: Home range, habitat selection, reproduction and behavior. J. Zool., vol. 210 , p. $599-612$

FONSECA, GAB., 1989. Small mammal species diversity in Brazilian tropical primary and secondary forests of different sizes. Rev. Bras. Zool., vol. 6, p. 381-422.
FONSECA, GAB. and KIERULFF, MC., 1989. Biology and natural history of brazilian Atlantic Forest small mammals. Bull. Florida Stat. Mus. Biol. Sci., vol. 34, p.99-152.

FONSECA, GAB. and ROBINSON, JG., 1990. Forest size and structure: competitive and predatory effects on small mammals communities. Biol. Conserv., vol. 53, p. 265-294.

GENTILE, R. and FERNANDEZ, FAS., 1999. Influence of habitat structure on a streamside small mammal community in a Brazilian rural area. Mammalia, vol. 63, no. 1, p. 29-40.

GENTILE, R., D'ANDREA, PS., CERQUEIRA, R. and MAROJA, LS., 2000. Population and reproduction of marsupials and rodents in a Brazilian rural area: a five-year study. Stud. Neotrop. Fauna \& Environ., vol. 35, p. 1-9.

GENTILE, R., FINOTTI, R., RADEMAKER, V. and CERQUEIRA, R., 2004. Population dynamics of four marsupials and its relation to resource production in the Atlantic Forest in southeastern Brazil. Mammalia, vol. 68, no. 2-3, p. 109-119.

GRELLE, CEV., 2003. Forest structure and vertical stratification of small mammals in a secondary Atlantic Forest, southeastern Brazil. Stud. Neotrop. Fauna \& Environ., vol. 38, p. 81-85.

HERRERA, HM., DÁVILA, AMR., NOREK, A., ABREU, UG., SOUZA, SS., D’ANDREA, PS. and JANSEN, AM., 2004. Enzootiology of Tripanosoma evansi in Pantanal, Brazil. Vet. Parasitol., vol. 125, no. 3-4, p. 263-275.

HERRERA, L., D'ANDREA, PS., XAVIER, SCC., MANGIA, RH., FERNÁNDEZ, O. and JANSEN, AM., 2005. Tripanosoma cruzi infection in wild mammals of the National Park "Serra da Capibara" and its surroundings (Piauí, Brazil), an area endemic for Chagas Disease. Trans. R. Soc. Trop. Med. Hyg., vol. 99, p. 379-388.

MAROJA, LS., ALMEIDA, FC. and SEUÁNEZ, HN., 2003. Genetic differentiation in nearby populations of Nectomys $s q$ uamipes in the Atlantic forest, Brazil. Genetics and Molecular Biology, vol. 26, no. 4, p. 403-410.

MILLS, JN., ELLIS, BA., MCKEE, KT., MAIZTEGUI, JI. and CHILDS, DJE., 1992a. Reproductive characteristics of rodent assemblage in cultivated regions of central Argentina. $J$. Mammal., vol. 73, no. 3, p. 515-526.

MILLS, JN., YATES, TL., CHILDS, JE., PARMENTER, RR., KSIAZEK, TG., ROLLIN, PE. and PETERS, CJ., 1992b. A longitudinal study of Júnin virus activity in the rodent reservoir of Argentine hemorragic fever. Am. J. Trop. Med. Hyg., vol. 47 , p. $749-763$.

MILLS, JN. and CHILDS, JE., 1998. Ecologic studies of rodents reservoirs: their relevance for human health. Emerg. Infect. Dis, vol. 4, no. 4, p. 529-537.

MOTTA, MFD., 1988. Estudo do desenvolvimento extra-uterino de Didelphis aurita Wied, 1826, em cativeiro - Investigação de critérios para estimativa de idade. MSc thesis, Universidade Federal do Rio de Janeiro - Museu Nacional, Rio de Janeiro.

NIMER, E., 1989. Climatologia do Brasil. IBGE Departamento de Recursos Naturais e Estudos Ambientais, Rio de Janeiro, 422p.

OLIVEIRA, FS., PIMEZ, C., PIRES, MQ., BRAZIL, RP. and PACHECO, RS., 2005. PCR-based diagnosis for detection of Leishmania in skin and blood of rodents from na endemic área of cutaneous and visceral leishmaniasis in Brazil. Vet. Parasitol., vol. 129, no. 3-4, p. 219-227. 
PADULA, P., FIGUEROA, R., NAVARRETI, M., PIZARRO, E., CADIZ, R., BELlOMO, C., JOFRE, C., ZAROR, L., RODRIGUEZ, E. and MURÚA, R., 2004. Transmission study of Andes Hantavirus infection in wild Sigmodontine rodents. J. Virol., vol. 78, no. 21, p. 11972-11979.

PARDINI, R., SOUZA, SM., BRAGA-NETO, R. and METZGER, JP., 2005. The role of Forest structure, fragment size and corridors in mainatining small mammal abundance and diversity in na Atlantic Forest landscape. Biol. Conserv., vol. 124, p. 253-266.

PEREIRA, LA., CHAGAS, WA. and COSTA, FE., 1993. Ecologia de pequenos mamíferos silvestres da Mata Atlântica, Brasil. I. Ciclos reprodutivos de Akodon cursor e Oryzomys nigripes (Rodentia, Cricetinae). Rev. Bras. Zool., vol. 10, p. 389398.

REY, L., 1993. Non-human vetebrate hosts of Schistosoma mansoni transmission in Brazil. Res. Rev. Parasitol., vol. 53, no. 1-2, p. $13-25$.

RODRÍGUEZ, JE., 1993. Roedores plaga: un problema permanente en América Latina y el Caribe. FAO, Oficina Regional para América Latina y el Caribe. Santiago, Chile.

SEBER, GAF., 1994. The estimation of animal abundance and related parameters. Edward Arnold, London, 2. ed., 672p.
SILVA, RR., SILVA, JRM., FAERSTEIN, NS., LENZI, HL. and REY, L., 1992. Natural infection of wild rodents of Schistosoma mansoni. Parasitological aspects. Mem. Inst. Oswaldo Cruz., vol. 87 , no. 1, p. 271-276.

STALLINGS, JR., 1989. Small mammals inventories in an easthern brazilian park. Bull. Florida State Mus., Biol. Sci., vol. 34, no. 4, p. 153-200.

STALLINGS, JR., FONSECA, GAB., PINTO, LPS., AGUIAR, LMS. and SÁBATO, EL., 1991. Mamíferos do Parque Florestal Estadual do Rio Doce, Minas Gerais, Brasil. Rev. Bras. Zool., vol. 7, no. 4, p. 663-677.

SUZUKI, A., BISORDI, I., LEVIS, S., GARCIA, J., PEREIRA, LE., SOUZA, RP., SUGAHARA, TKN., PINI, N., ENRIA, D., SOUZA, LTM., 2004. Identifying rodent hantavirus reservoirs, Brazil. Emerg. Infect. Dis., vol. 10, no. 12, p. 2127-2134.

UTRERA, A., DUNO, G., ELLIS, BA., SALAS, RA., MANZIONE, N., FULHORST, CF., TESH, RB. and MILLS, JN., 2000. Small mammals in agricultural areas of the western llanos of Venezuela: community structure, habitat associations, and relative densities. J. Mammal., vol. 81, no. 2, p. 536-548.

ZAR, JH., 1996. Biostatistical Analysis. Prentice Hall, Englewood Cliffs, New Jersey,. 662p. 